AKUNTANSI: Jurnal Akuntansi Integratif

Vol.6 No. 2 Tahun 2020

p-ISSN 2502-5376 e-ISSN 2715-0658

\title{
FAKTOR PENENTU PEMAHAMAN MAHASISWA AKUNTANSI ERA COVID19 (STUDI EMPIRIS MAHASISWA AKUNTANSI DI JAWA TIMUR)
}

\author{
Ajeng Tita Nawangsari \\ Universitas Islam Negeri Sunan Ampel Surabaya \\ Email: ajeng.tita@uinsby.ac.id
}

\begin{abstract}
ABSTRAK
Penelitian ini bertujuan untuk menguji apakah secara empiris variabel learning from home yang merepresentasikan sikap dan perilaku mahasiswa akuntansi dan variabel ketersediaan Information Technology (IT) berpengaruh terhadap pemahaman akuntansi mahasiswa di Jawa Timur selama masa pandemi Covid19. Penelitian ini menggunakan pendekatan kuantitatif yang dimaksudkan untuk menguji secara empiris faktor-faktor penentu pemahaman mahasiswa akuntansi pada era Covid19. Metode pengambilan sampel dilakukan dengan menggunakan teknik proportional random sampling sedangkan data diambil dengan menggunakan metode survey melalui kuesioner online. Hasil penelitian menunjukan bahwa variabel learning from home dan ketersediaan IT berpengaruh secara positif signifikan terhadap pemahaman akuntansi mahasiswa.
\end{abstract}

Kata kunci: Learning from home, Pemahaman Akuntansi, Ketersediaan Information Technology, Covid19

\section{ABSTRACT}

This study aims to provide empirical evidence regarding the factors that affect student's understanding in accounting during Covid 19 pandemic in East Java. There are there variables tested which are learning from home that represent the attitude and behavior of accounting students, the avalilability of IT and students understanding regarding the accounting knowledge. This study is a quantitative method to empirically tested those factors. Sampling method was carried out using a proportional random sampling technique and data was collected using a survey method through an online questionnaire. The results showed that the learning from home variable and the availability of IT had a significant positive effect on students' accounting understanding.

Keywords: Learning from home, Accounting Understanding, Information Technology Availability, Covid19

\section{Pendahuluan}

Penghujung tahun 2019, kita semua dikagetkan dengan kemunculan virus misterius di Wuhan China yang menyebabkan Pneumonia. World Health Organization sejak Maret 2020 telah menetapkan virus yang dinamakan sebagai Covid 19 itu sebagai fenomena pandemic Global karena penyebarannya yang sangat masif di berbagai negara tak terkecuali di Indonesia. Sejak pertama kali presiden Joko Widodo mengumumkan bahwa ada dua pasien Covid19 pada hari senin 2 Maret 2020 seperti yang dilansir Detik News, jumlah pasien Corona terus 
mengalami kenaikan sampai dengan saat ini. Untuk menanggulangi wabah Covid19, pemerintah kemudian menerapkan beberapa kebijakan srategis seperti penerapan Pembatasan Sosial Berskala Besar (PSBB) yang diatur dalam Peraturan Pemerintah Republik Indonesia Nomor. 21 Tahun 2020. Mengacu pada PP tersebut, pembatasan sosial berskala besar paling sedikit meliputi peliburan sekolah dan tempat kerja, pembatasan kegiatan keagamaan, pembatasan kegiatan di tempat atau fasilitas umum. Dengan adanya kebijakan tersebut, sejak bulan Maret 2020 sekolah di Indonesia tidak lagi menerapkan pembelajaran tatap muka di kelas tetapi dilakukan dengan menggunakan metode e-learning dengan memanfaatkan berbagai teknologi informasi sebagai media pembelajaran.

Sebelum adanya pandemic Covid19 sebenarnya konsep e-learning sudah didengungkan terutama pada sistem pembelajaran di pendidikan tinggi. Hal tesebut karena sudah sejak lama konsep pembelajaran di Indonesia dipersiapkan untuk menghadapi era revolusi industri 4.0. Hartanto (2019) menyebutkan bahwa untuk dapat melaksankan pembelajaran yang baik pada era revolusi industri 4.0 diperlukan kesiapan teknologi dalam menunjang pembelajaran. Teknologi yang digunakan dalam kegiatan e-learning menurut Astuti dan Febrian (2019) diantaranya adalah interactive tv, internet, audio video tape, cd room, platform pembelajaran online seperti google classroom dan lain sebaginya. Selain teknologi, beberapa hal seperti dukungan layanan belajar dan manajemen pengelolaan waktu pada saat belajar daring juga menjadi faktor yang menunjang kesiapan dan keberhasilan $e$ learning. Hartono (2016) menyatakan bahwa tersedianya dukungan layanan dan pengelolaan waktu yang dilakukan baik oleh mahasiswa maupun dosen saat melaksanakan e-learning dapat membantu mahasiswa memahami meteri yang disampaikan. Keberhasilan pembelajaran $e$ learning ini sangat penting untuk dapat dicapai dan dievaluasi karena pandemi covid 19 mungkin akan berlangsung dalam waktu yang masih belum bisa ditentukan. Hal lain, $e$ learning sendiri sudah harus menjadi suatu kebiasaan terutma bagi jenjang pendidikan tinggi untuk dapat bersaing pada era industri 4.0 ini. E-learning merupakan solusi yang efektif agar capaian pembelajaran dapat dicapai dengan baik selama masa pandemi. Hal ini disebabkan karena selama masa pandemi pembelajaran tatap muka atau luring tidak disarankan mengingat penyebaran virus Covid19 harus bisa dikendalikan. Penelitian yang dilakukan oleh Hanum dan Sulistiyo ( 2013) dalam penelitiannya tentang keefektifan e-learning menyatakan bahwa elearning terbukti efektif dalam mencapai tujuan pembelajaran. Hal tersebut membuat elearning menjadi hal yang esensial saat ini.

Sejalan dengan itu, penelitian ini sendiri bertujuan untuk dapat membuktikan secara empiris apakah faktor seperti bagaimana sikap dan perilaku mahasiswa dapat mempengaruhi pemahaman akuntansi. Hal ini dilakukan untuk memberikan bukti empiris yang kuat mengenai bagaimana keberhasilan e-learning pada mahasiswa akuntansi dapat dicapai melalui pemenuhan ketersediaan IT dan pembentukan karakter dan sikap yang sesuai. Selain untuk dapat memberikan bukti empiris yang objektif penelitian ini juga dapat dijadikan bahan evaluasi baik bagi pihak universitas maupun dari regulator terutama terkait dengan ketersediaan IT yang harus dipenuhi dalam rangka menunjang kegiatan e-learning selama pandemi Covid 19 berlangsung.

\section{Kajian Pustaka}

Sistem Pembelajaran E-Learning

Menurut Amasha dan AbdElrazek (2016) E-leaning merupakan sebuah kegiatan yang melibatkan penggunaan teknologi informasi dalam rangka meyebarkan pengetahuan dan informasi untuk kepentingan pendidikan melalui jaringan komputer, perangkat seluler, komuniasi nirkabel dan media lainnya yang sesuai. Beberapa penelitian tentang penggunaan $e$ learning dilakukan oleh Stricker, Weibel dan Wissmath (2011) yang meneliti tentang perbandingan hasil belajar dua grup siswa dengan dua model pembelajaran yang berbeda. Grup 
A merupakan grup yang menggunakan e-learning dalam proses belajar dan grup B merupakan grup yang menggunakan tatap muka langsung tanpa e-leaning. Hasil penelitian menunjukan bahwa grup A ternyata mempunyai prestasi belajar dan pemahaman yang lebih baik dibandingkan dengan grup B. Penelitian tersebut memberikan pandangan bahwa sebenarnya proses e-learning bukan merupakan hambatan dan kendala dalam tersampaikannya materi dengan baik. Cheng (2011) dalam penelitiannya tentang Faktor prediktor penerimaan pembelaaran E-learning menyatakan bahwa faktor-faktor penerimaan e-learning diantaranya adalah kebermanfaatan e-learning dibandingkan dengan metode konvensional, kemudahan dalam pengunaan e-learning, ekternalitas jaringan, kesiapan individu dan kesiapan sosial. Selain itu, tersedianya tutor, dukungan dari universitas, Teknologi indormasi yang memadai juga menjadi faktor yang mempengaruhi keberhasilan pembelajaran e-learning yang dapat diamati dari meningkatnya pemahaman siswa terhadap materi yang disampaikan. Sarana dan prasana memang sangat penting tetapi faktor lain seperti sikap siswa dan instruktur dalam hal ini adalah dosen juga penting. Liaw, Huang, dan Chen (2007) menyatakan bahwa, beberapa penelitian yang berkaitan dengan pengukuran keberhasilan proses pembelajaran e-learning sudah tidak berfokus pada sarana dan prasarana yang mendukung e-learning tetapi juga pada sikap dan interaksi antara siswa/mahasiswa dengan guru/dosennya sebagai faktor dominan yang menentukan keberhasilan e-learning.

Keberhasilan Sistem Informasi

Penelitian tentang keberhasilan sistem informasi dalam menunjang pembelajaran $e$ learning yang dilakukan oleh Delone dan McLean (1992);Cidral, Oliveira, dan Aparico (2018)' Samarasinghae dan Tretiakov (2009); Romi, I. M. (2017) menghasilkan kesimpulan bahwa model keberhasilan sistem informasi merupakan kombinasi dari faktor-faktor seperti kualitas sistem yang berhubungan liner degan karakteristik teknologi, kinerja dan kegunaan dari sistem itu sendiri. Sedangkan kualitas informasi berhubungan dengan keakuratan dan validitas sistem. Kualitas layanan berhubungan dengan daya tanggap dan kompetensi dari staff IT yang dimiliki oleh organisasi. Kegunaan dari sistem informasi juga merupakan faktor pendukung keberhasilan sistem informasi. Kegunaan ini sendiri diukur dengan menggunakan keefektivan sistem sedangkan kepuasan pengguna diukur dengan kesesuaian sistem informasi dengan kebutuhan pngguna dan keberhasilan sistem informasi dalam meningkatkan efisiensi kerja baik secara individu maupun organisasi.

Pengembangan Hipotesis

Penelitian ini bertujuan untuk mencari hubungan antara learning from home, ketersediaan IT dan pemahaman akuntansi. Learning from home ini berisi indikator-indikator yang merepresentasikan faktor-faktor pendukung keberhasilan e-learning sesuai dengan penelitian yang dilakukan oleh Liaw, Huang, dan Chen (2007) yaitu sikap dan perilaku mahasiswa dalam mensikapi pembelajaran e-learning. Beberapa indikator yang dimaksud adalah pengelolaan waktu belajar, kenyamanan lingkungan untuk e-learning, dan fleksibilitas dalam pengaturan materi belajar saat e-learning. Sikap dan perilaku yang ditunjukan mahasiswa tersebut diharapkan dapat menunjang kenyamanan belajar saat e-learning yang nantinya akan dapat meningkatkan pemahaman mahasiswa terhadap pemahaman Akuntansi. Sedangkan ketersediaan IT dijabarkan dengan kesiapan IT organisasi dan individu dalam melaksankan e-learning. Beberapa indikator yang digunakan untuk mengukur ketersediaan IT diantaranya adalah fasilitas e-learning di rumah mahasiswa yang mencukupi, kesediaan pengajar (dosen) untuk menggunakan fasilitas penunjang pembelajaran e-learning yang telah disediakan oleh pihak kampus dengan baik, ketersidiaan fasilitas e-learning dari pihak kampus yang memadai, kemudahan menggunakan teknologi informasi dalam menunjang pembelajaran e-learning. Variabel independen dalam penelitian ini adalah pemahaman akuntansi mahasiswa. Indikator pengukur yang digunakan diantaranya adalah pemahaman tentang akuntansi keuangan yang meliputi pemahaman akan hutang jangka pendek, panjang, proses akuisisi 
perusahaan, penjualan konsinyasi. Selain akuntansi keuangan, indikator pemahamn akuntansi biaya dan investasi juga dilibatkan. Beberapa variabel tersebut memang dikembangkan berdasarkan penelitian oleh Liaw, Huang, dan Chen (2007). Studi yang dilakukan mereka menghasilkan model penggunaan teknologi dimana keberhasilan penggunaan teknologi bisa dinilai dari beberapa faktor yaitu ketersediaan teknologi, konten yang akan disampaikan melalui teknologi dan sikap serta interaksi para pengguna teknologi tersebut. Selain Liaw, Huang, dan Chen (2007), variabel dalam penelitian ini juga mengacu pada penelitian yang dilakukan oleh Cheng (2011), Delone dan McLean (1992) tentang faktor prediktor penerimaan e-learning dan keberhasilan sistem informasi dalam menunjang pembelajaran $e$-leraning.

Peneliti sendiri bermaksud untuk membuktikan hubungan diantara variabel seperti learning from home yang merepresentasikan perilaku mahasiswa dalam mensikapi pembelajaran e-learning terhadap pemahaman akuntansi. Pemahaman akuntansi yang dimaksud merupakan pemahaman baik yang bersifat teoritis maupun aplikatif. Apakah dengan adanya kesiapan mahasiswa, dosen dan organisasi dalam mempersiapkan pembelajaran $e$ learning dapat meningkatkan pemahaman akuntansi para mahasiswa. Berdasarkan penelitian terdahulu yang dilakukan oleh Gel et al (2014) menemukan adanya hasil positif signifikan antara perilaku pengguna e-learning terhadap hasil belajar siswa. Selain itu, aspek perilaku penelitian ini juga bermaksud untuk mengetahui apakah ketersediaan IT yang memadai juga menjadi faktor signifikan dalam pembentukan pemahaman akuntansi pada pembelajaran $e$ learning. Pavel et al (2015) dalam penelitiannya menyaakan bahwa ketersediaan teknologi informasi dan internet dapat meningkatkan kualitas pemahaman pembelajaran. Penelitian Pavel tersebut juga didukung oleh hasil penelitian yang dilaukan oleh Halawi et al (2009) tentang bagaimana ketersediaan teknologi informasi yang memadai menunjang keberhasilan pembelajaran e-learning. Berdasarkan konstruk model berfikir dari Liaw, Huang, dan Chen (2007), maka hipotesis yang diajukan dalam penelitian ini dinyatakan sebagai berikut:

1. Learning From Home berpengaruh secara signifikan positif terhadap pemahaman akuntansi mahasiswa ( $\mathrm{H} 1)$

2. Ketersediaan IT berpengaruh secara signifikan positif terhadap pemahaman akuntansi mahasiswa $(\mathrm{H} 2)$

3. Learning From Home dan Ketersediaan IT secara bersama berpengaruh secara positif signifikan terhadap pemahaman akuntansi mahasiswa (H3)

Kerangka Konseptual

Dari paparan teori dan pengembangan hipotesis diatas maka kerangka konseptual penelitian bisa digambarkan sebagai berikut:

\section{Gambar 1}

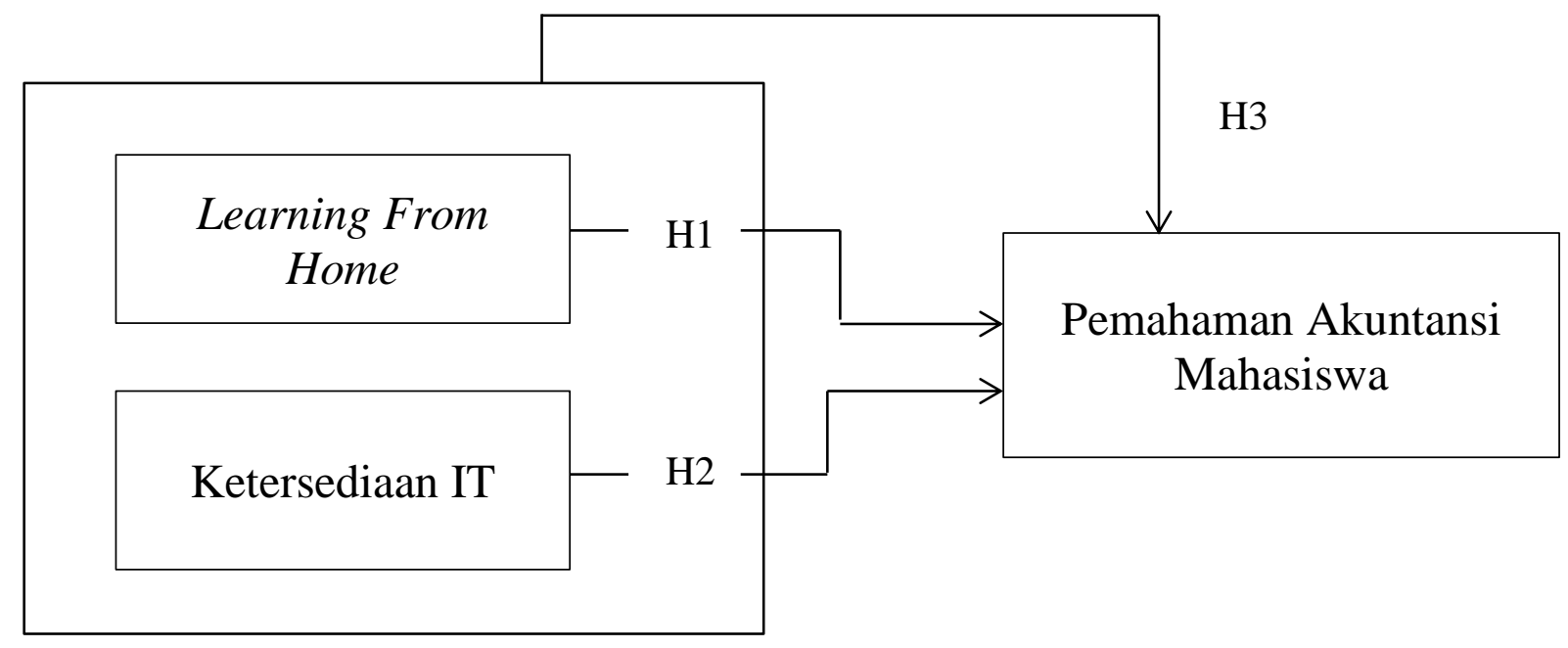




\section{Metode Penelitian}

Identifikasi Variabel dan Pengukurannya

Variabel Dependen

Variabel dependen yang digunakan dalam penelitian ini adalah pemahaman mahasiswa (Y) yang diukur dengan menggunakan beberapa indikator yaitu pemahaman atas akuntansi keuangan, biaya dan investasi

Variabel Independen

Variabel independen dalam penelitian ini adalah variabel Learning from home (X1) dan Ketersediaan IT (X2)

\section{Populasi dan Sampel}

Populasi dalam penelitian ini adalah seluruh mahasiswa akuntansi semester 6 dan 8 yang diambil dari semua universitas yang ada di Jawa Timur. Universitas yang masuk ke dalam populasi penelitian sendiri terdiri dari universitas negeri non keislaman dan keislaman pada jenjang Pendidikan S1. Teknik pengambilan sampel dilakukan secara proportional random sampling dengan menggunakan kriteria yaitu mahasiswa tersebut merupakan mahasiswa semester 6 dan 8, sedang atau telah menempuh mata kuliah akuntansi yang berhubungan dengan baik akuntansi keuangan, biaya dan invstasi dan merupakan mahasiswa yang terdaftar di universitas yang ada di Jawa Timur. Dari hasil penyamplingan tersebut didapatkan 374 orang mahasiswa yang dapat dijadikan sampel dalam penelitian ini.

Metode Analisis

Analisis Statistik Deskriptif

Statistik deskriptif adalah sebuah metode yang digunakan untuk mengetahui sebaran data melalui ukuran-ukuran statistika misalnya adalah mean, median dan standar deviasi. Hal ini dilakukan untuk mendapatkan gambaran secara umum tentang data penelitian yang diolah (Sugiyono,2009).

Uji Validitas dan Reliabilitas

Uji validitas dan reliabilitas dilakukan untuk mengetahui seberapa sesuai dan handal suatu instrumen penelitian. Instrumen penelitian sendiri digunakan untuk mengambil data. Arikunto (2010) menyatakan bahwa sesuai tidaknya data penelitian yang diambil dengan tujuan peneltian tergantung dari konstruk instrumen penelitian itu sendiri. Validitas instrumen penelitian ini digunakan untuk mengetahui kesesuaian antara ketepatan item yang digunakan untuk mengukur dengan apa yang akan diukur. Sedangkan reliabilitas digunakan untuk mengukur sejauh mana instrumen penelitian yang digunakan dapat dipercaya keajegannya. Uji Asumsi Klasik

\section{Uji Normalitas}

Uji normalitas dilaksanakan untuk mengetahui apakah model regresi dalam penelitian terdistribusi secara normal. Uji normalitas dalam penelitian ini menggunakan one sample Kolmogorov smirnov.

Uji Multikolinearitas

Uji multikolinearitas merupaka uji asumsi klasik yang dilaksankan untuk mengetahui apakah antar vaiabel dalam penelitian terdapat korelasi. Uji multikolinearitas ini dilakukan dengan nilai Variance inflation factor-nya.

Uji Heteroskedastisitas

Uji heteroskedastisitas merupakan uji asumsi klasik yang digunakan untuk mengetahui apakah terjadi penyimpangan dari syarat-syarat asumsi klasik pada model regresi linear. Uji heteroskedastisitas dalam penelitian ini dilakukan dengan menggunakan metode scatter plot. 
Uji regresi

Uji hipotesis dalam penelitian ini dilakukan dengan menggunakan uji regresi berganda. Persamaan regresi dituliskan sebagai berikut:

$$
\mathrm{Y}=\alpha+\beta 1 \mathrm{X} 1+\beta 2 \mathrm{X} 2+e
$$

Y $($ Dependen variable $)=$ Pemahaman Akuntansi

$\mathrm{X} 1$ (Independent Variable 1)= Learning from home

X2 (Independent Variable 2) $=$ Ketersediaan IT

$\beta 1-\beta 2=$ Koefisien persamaan regresi

$\alpha=$ Konstanta persamaan regresi

Hasil dan Pembahasan

Analisis Data dan Pembahasan

Analisis Statistik Deskriptif

Tabel 1

Analisis Statistik Deskriptif

\begin{tabular}{|l|r|r|r|r|r|}
\hline \multicolumn{7}{|c|}{ Descriptive Statistics } \\
\hline & $\mathrm{N}$ & Minimum & Maximum & Mean & $\begin{array}{c}\text { Std. } \\
\text { Deviation }\end{array}$ \\
\hline $\begin{array}{l}\text { Learning from } \\
\text { home }\end{array}$ & 374 & 9.00 & 45.00 & 33.6390 & 5.45325 \\
\hline Ketersediaan IT & 374 & 6.00 & 30.00 & 22.2112 & 3.56867 \\
\hline $\begin{array}{l}\text { Pemahaman } \\
\text { Akuntansi }\end{array}$ & 374 & 11.00 & 55.00 & 39.8449 & 6.27840 \\
\hline Valid N (listwise) & 374 & & & & \\
\hline
\end{tabular}

Dari data yang terdapat dalam tabel 1 analisis deskriptif merupakan salah satu uji statistik yang berfungsi untuk mendeskripsikan gambaran terhadap objek yang diteliti. Objek penelitian adalah mahasiswa yang tersebar di seluruh Jawa Timur dari semester 6 dan 8 sebanyak 374 mahasiswa. Data diambil dengan menggunakan kuesioner yang disebarkan secara online dimana tiap-tiap pertanyaanya diukur dengan menggunakan skala likert dari 1 sampai dengan 5. Dalam data dapat diamati bahwa variabel Learning from home mempunyai nilai maksimum sebesar 45.00, minimum 9.00 dan rata-ratanya adalah 33.64. Variabel ketersediaan IT mempunyai nilai minimum sebanyak 6 dan maksimum sebanyak 30 dengan rata-rata nya adalah sebesar 22.21. Terakhir variabel Pemahaman akuntansi mempunyai nilai minum 11, maksimum 39.84 dan rata-rata sebanyak 39.84. Sedangkan stander deviasi dari masing-masing variabel dalam penelitian ini adalah sebesar 5.45, 3.56 dan 5.27. 
Uji Validitas dan Reliabilitas

a. Learning From Home

Tabel 2

Uji Validitas Learning From Home

\begin{tabular}{|c|c|c|}
\hline \multicolumn{3}{|c|}{ Correlations } \\
\hline & & $\begin{array}{l}\text { Learning } \\
\text { from home }\end{array}$ \\
\hline \multirow[t]{3}{*}{$\mathrm{X} 11$} & $\begin{array}{l}\text { Pearson } \\
\text { Correlation }\end{array}$ & $.753^{* *}$ \\
\hline & Sig. (2-tailed) & .000 \\
\hline & $\mathrm{N}$ & 374 \\
\hline \multirow[t]{3}{*}{$\mathrm{X} 12$} & $\begin{array}{l}\text { Pearson } \\
\text { Correlation }\end{array}$ & $.706^{* *}$ \\
\hline & Sig. (2-tailed) & .000 \\
\hline & $\mathrm{N}$ & 374 \\
\hline \multirow[t]{3}{*}{$\mathrm{X} 13$} & $\begin{array}{l}\text { Pearson } \\
\text { Correlation }\end{array}$ & $.682^{* *}$ \\
\hline & Sig. (2-tailed) & .000 \\
\hline & $\mathrm{N}$ & 374 \\
\hline \multirow[t]{3}{*}{$\mathrm{X} 14$} & $\begin{array}{l}\text { Pearson } \\
\text { Correlation }\end{array}$ & $.734^{* *}$ \\
\hline & Sig. (2-tailed) & .000 \\
\hline & $\mathrm{N}$ & 374 \\
\hline \multirow[t]{3}{*}{ X15 } & $\begin{array}{l}\text { Pearson } \\
\text { Correlation }\end{array}$ & $.621^{* *}$ \\
\hline & Sig. (2-tailed) & .000 \\
\hline & $\mathrm{N}$ & 374 \\
\hline \multirow[t]{3}{*}{$\mathrm{X} 16$} & $\begin{array}{l}\text { Pearson } \\
\text { Correlation }\end{array}$ & $.716^{* * *}$ \\
\hline & Sig. (2-tailed) & .000 \\
\hline & $\mathrm{N}$ & 374 \\
\hline \multirow[t]{3}{*}{$\mathrm{X} 17$} & $\begin{array}{l}\text { Pearson } \\
\text { Correlation }\end{array}$ & $.713^{* *}$ \\
\hline & Sig. (2-tailed) & .000 \\
\hline & $\mathrm{N}$ & 374 \\
\hline \multirow[t]{3}{*}{$\mathrm{X} 18$} & $\begin{array}{l}\text { Pearson } \\
\text { Correlation }\end{array}$ & $.741^{* *}$ \\
\hline & Sig. (2-tailed) & .000 \\
\hline & $\mathrm{N}$ & 374 \\
\hline \multirow[t]{3}{*}{ X19 } & $\begin{array}{l}\text { Pearson } \\
\text { Correlation }\end{array}$ & $.721^{* * *}$ \\
\hline & Sig. (2-tailed) & .000 \\
\hline & $\mathrm{N}$ & 374 \\
\hline
\end{tabular}

**. Correlation is significant at the 0.01

level (2-tailed).

Berdasarkan tabel 2 di atas bisa dilihat bahwa nilai r (person correlation) indikator X11 sampai dengan X19 lebih besar dari 0.30, maka dinyatakan valid. 
Tabel 3

Uji Reliabilitas Learning From Home

\begin{tabular}{|r|r|}
\hline \multicolumn{2}{|c|}{ Reliability Statistics } \\
\hline $\begin{array}{c}\text { Cronbach's } \\
\text { Alpha }\end{array}$ & $\begin{array}{c}\text { N of } \\
\text { Items }\end{array}$ \\
\hline .876 & 9 \\
\hline
\end{tabular}

Berdasarkan uji reliabilitas yang dilihat pada tabel 3 dari variabel learning from home, diketahui bahwa kesembilan indikator yaitu dari X11 sampai dengan X19 secara bersama mepunyai nilai Croncbach's Alpha sebesar 0.876 nilai tersebut lebih besar dibandingkan dengan 0.60 sebagai batas ukuran reliabilitas. Oleh karena itu, maka kesembilan indikator tersebut dinyatakan reliable.

b. Ketersediaan IT

Tabel 4

Uji Validitas Ketersediaan IT

\begin{tabular}{|c|c|c|}
\hline \multicolumn{3}{|c|}{ Correlations } \\
\hline & & $\begin{array}{c}\text { Ketersediaan } \\
\text { IT } \\
\end{array}$ \\
\hline \multirow[t]{3}{*}{$\begin{array}{l}\mathrm{X} 2 \\
1\end{array}$} & $\begin{array}{l}\text { Pearson } \\
\text { Correlation }\end{array}$ & $.677^{\text {** }}$ \\
\hline & Sig. (2-tailed) & .000 \\
\hline & $\mathrm{N}$ & 374 \\
\hline \multirow[t]{3}{*}{$\begin{array}{l}\mathrm{X} 2 \\
2\end{array}$} & $\begin{array}{l}\text { Pearson } \\
\text { Correlation }\end{array}$ & $.716^{* * *}$ \\
\hline & Sig. (2-tailed) & .000 \\
\hline & $\mathrm{N}$ & 374 \\
\hline \multirow[t]{3}{*}{$\begin{array}{l}\mathrm{X} 2 \\
3\end{array}$} & $\begin{array}{l}\text { Pearson } \\
\text { Correlation }\end{array}$ & $.789^{* * *}$ \\
\hline & Sig. (2-tailed) & .000 \\
\hline & $\mathrm{N}$ & 374 \\
\hline \multirow[t]{3}{*}{$\begin{array}{l}X 2 \\
4\end{array}$} & $\begin{array}{l}\text { Pearson } \\
\text { Correlation }\end{array}$ & $.748^{* *}$ \\
\hline & Sig. (2-tailed) & .000 \\
\hline & $\mathrm{N}$ & 374 \\
\hline \multirow[t]{3}{*}{$\begin{array}{l}X 2 \\
5\end{array}$} & $\begin{array}{l}\text { Pearson } \\
\text { Correlation }\end{array}$ & $.598^{* * *}$ \\
\hline & Sig. (2-tailed) & .000 \\
\hline & $\mathrm{N}$ & 374 \\
\hline \multirow[t]{3}{*}{$\begin{array}{l}X 2 \\
6\end{array}$} & $\begin{array}{l}\text { Pearson } \\
\text { Correlation }\end{array}$ & $.564^{* *}$ \\
\hline & Sig. (2-tailed) & .000 \\
\hline & $\mathrm{N}$ & 374 \\
\hline
\end{tabular}

Dapat diamati pada tabel 4 bahwa nilai $\mathrm{r}$ (pearson correlation) dari indikator X21 sampai dengan X26 lebih besar dari 0.30 oleh karena itu maka indikator X21-X26 dinyatakan valid untuk digunakan dalam pengambilan data. 
Tabel 5

Uji Reliabilitas Ketersediaan IT

\begin{tabular}{|c|c|}
\hline \multicolumn{2}{|c|}{ Reliability Statistics } \\
\hline $\begin{array}{c}\text { Cronbach's } \\
\text { Alpha }\end{array}$ & $\begin{array}{c}\text { N of } \\
\text { Items }\end{array}$ \\
\hline .767 & 6 \\
\hline
\end{tabular}

Untuk uji reliabilitas yang dapat dilihat pada tabel 5 di atas secara bersama-sama dari indikator X21 sampai dengan X26 mempunyai nilai Cronchach's Alpha sebesar 0.767. Nilai ini lebih besar dari nilai 0.60 oleh karenanya indikator tersebut lolos uji reliabilitas.

c. Pemahaman Akuntansi

Tabel 6

Uji Validitas Pemahaman Akuntansi

\begin{tabular}{|c|c|c|}
\hline \multicolumn{3}{|c|}{ Correlations } \\
\hline & & $\begin{array}{l}\text { Pemahaman } \\
\text { Akuntansi }\end{array}$ \\
\hline \multirow[t]{3}{*}{ Y1 } & Pearson Correlation & $.830^{* * *}$ \\
\hline & Sig. (2-tailed) & .000 \\
\hline & $\mathrm{N}$ & 374 \\
\hline \multirow[t]{3}{*}{$\mathrm{Y} 2$} & Pearson Correlation & $.825^{* *}$ \\
\hline & Sig. (2-tailed) & .000 \\
\hline & $\mathrm{N}$ & 374 \\
\hline \multirow[t]{3}{*}{ Y3 } & Pearson Correlation & $.784^{* *}$ \\
\hline & Sig. (2-tailed) & .000 \\
\hline & $\mathrm{N}$ & 374 \\
\hline \multirow[t]{3}{*}{ Y4 } & Pearson Correlation & $.796^{* *}$ \\
\hline & Sig. (2-tailed) & .000 \\
\hline & $\mathrm{N}$ & 374 \\
\hline \multirow[t]{3}{*}{ Y5 } & Pearson Correlation & $.769^{* *}$ \\
\hline & Sig. (2-tailed) & .000 \\
\hline & $\mathrm{N}$ & 374 \\
\hline \multirow[t]{3}{*}{ Y6 } & Pearson Correlation & $.751^{* *}$ \\
\hline & Sig. (2-tailed) & .000 \\
\hline & $\mathrm{N}$ & 374 \\
\hline \multirow[t]{3}{*}{ Y7 } & Pearson Correlation & $.725^{* *}$ \\
\hline & Sig. (2-tailed) & .000 \\
\hline & $\mathrm{N}$ & 374 \\
\hline \multirow[t]{3}{*}{ Y8 } & Pearson Correlation & $.766^{* *}$ \\
\hline & Sig. (2-tailed) & .000 \\
\hline & $\mathrm{N}$ & 374 \\
\hline \multirow[t]{3}{*}{ Y9 } & Pearson Correlation & $.794^{* *}$ \\
\hline & Sig. (2-tailed) & .000 \\
\hline & $\mathrm{N}$ & 374 \\
\hline \multirow[t]{3}{*}{ Y10 } & Pearson Correlation & $.763^{* *}$ \\
\hline & Sig. (2-tailed) & .000 \\
\hline & $\mathrm{N}$ & 374 \\
\hline \multirow[t]{3}{*}{ Y11 } & Pearson Correlation & $.758^{* *}$ \\
\hline & Sig. (2-tailed) & .000 \\
\hline & $\mathrm{N}$ & 374 \\
\hline
\end{tabular}

tailed).

Dari tabel 6 di atas nilai masing-masing dari indikator Y3 sampai dengan Y11 lebih besar dari 0.30 maka dikatakan indikator tersebut valid. 
Tabel 7

Uji Reliabilitas Pemahaman Akuntansi

\begin{tabular}{|c|c|}
\hline \multicolumn{2}{|c|}{ Reliability Statistics } \\
\hline $\begin{array}{c}\text { Cronbach's } \\
\text { Alpha }\end{array}$ & $\begin{array}{c}\text { N of } \\
\text { Items }\end{array}$ \\
\hline .935 & 11 \\
\hline
\end{tabular}

Dari data yang diketahui pada tabel 7 bahwa nilai cronchbach's Alpha pada pengetesan reliabilitas adalah 0.935 dimana lai rsebut lebibesar di 0.60 maka dapat dikatakan indikator tersebut reliable.

Uji Asumsi Klasik

a. Uji Normalitas

Tabel 8

Uji Normalitas

\begin{tabular}{|l|l|r|}
\hline \multicolumn{2}{|c|}{ One-Sample Kolmogorov-Smirnov Test } \\
\hline N & $\begin{array}{c}\text { Unstandardize } \\
\text { d Residual }\end{array}$ \\
\hline Normal Parameters & Mea & 374 \\
\cline { 2 - 3 } & Std. & .0000000 \\
\hline Most Extreme & Deviation & 4.82844880 \\
Differences & Absolute & .035 \\
\cline { 2 - 3 } & Positive & .034 \\
\cline { 2 - 3 } & Negative & -.035 \\
\hline Test Statistic & .035 \\
\hline Asymp. Sig. (2-tailed) & $.200^{\mathrm{c}, \mathrm{d}}$ \\
\hline
\end{tabular}

Tabel 8 diketahui bahwa uji normalitas pada penelitian ini menggunakan uji kolomogorov smirnov dengan hasil signifikansi sebesar 0.200 lebih besar dari signifikansi 0.05 sehingga ba disiulkan bahwa data dalam penelitian ini terdistribusi secara normal. 
b. Uji Multikolinearitas

Tabel 9

Uji Multikolinearitas

\begin{tabular}{|c|c|c|c|c|c|c|c|c|}
\hline \multicolumn{9}{|c|}{ Coefficients $^{\mathbf{a}}$} \\
\hline \multirow{2}{*}{\multicolumn{2}{|c|}{ Model }} & \multicolumn{2}{|c|}{$\begin{array}{l}\text { Unstandardized } \\
\text { Coefficients }\end{array}$} & \multirow{2}{*}{$\begin{array}{c}\text { Standardi } \\
\text { zed } \\
\text { Coefficie } \\
\text { nts } \\
\text { Beta }\end{array}$} & \multirow[t]{2}{*}{$\mathrm{t}$} & \multirow[t]{2}{*}{ Sig. } & \multicolumn{2}{|c|}{$\begin{array}{l}\text { Collinearity } \\
\text { Statistics }\end{array}$} \\
\hline & & B & Std. Error & & & & $\begin{array}{c}\text { Tolera } \\
\text { nce }\end{array}$ & VIF \\
\hline \multirow[t]{3}{*}{1} & (Constant) & 12.492 & 1.756 & & 7.115 & .000 & & \\
\hline & $\begin{array}{l}\text { Learning from } \\
\text { home }\end{array}$ & .548 & .057 & .476 & 9.554 & .000 & .642 & 1.557 \\
\hline & Ketersediaan IT & .402 & .088 & .228 & 4.583 & .000 & .642 & 1.557 \\
\hline
\end{tabular}

a. Dependent Variable: Pemahaman Akuntansi

Tabel 9 menjelaskan data terkait uji multikolinearitas merupakan salah satu bagian dari pengujian asumsi klasik yang digunakan untuk melihat apakah pada model regresi yag diuji terdapat kolinearitas diantara variabel bebasnya. Pada tabel diatas diketahui bahwa nilai VIF variabel bebas pada model regresi ini adalah sebesar 1.557 dimana nilai tersebut < 10 maka dapat dikatakan bahwa model regresi yang diajukan terbebas dari masalah multikolinearitas.

c. Uji Heteroskedastisitas

Gambar 2

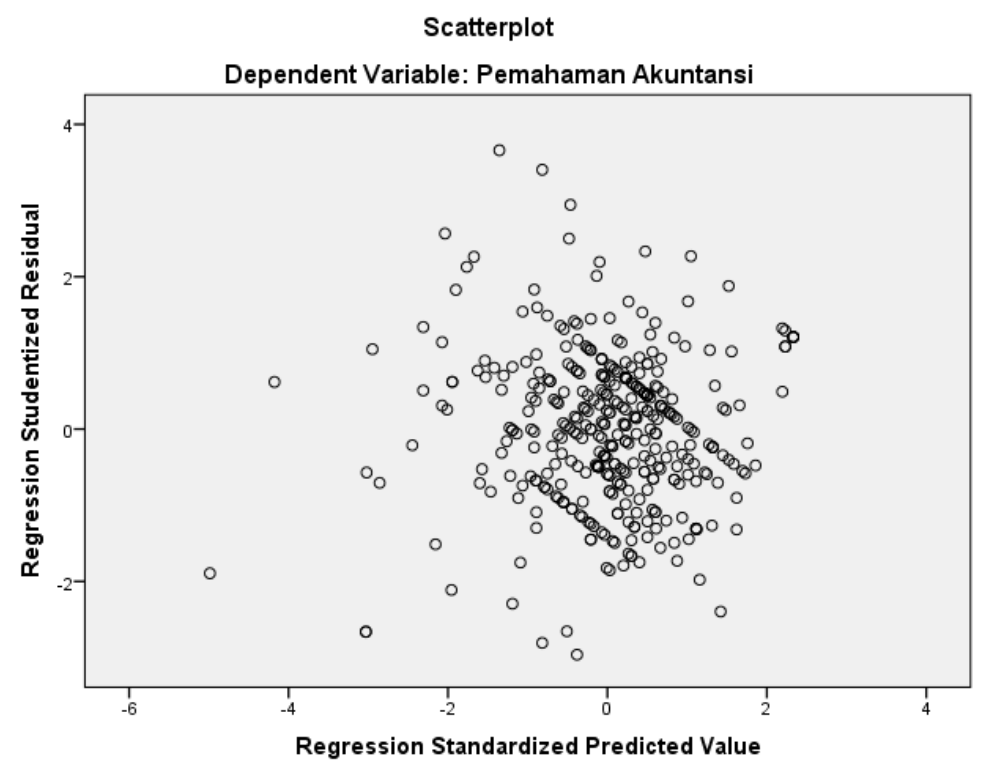

Uji heteroskedastisitas yang dikeathui gambar 2 di atas, pada penelitian ini dilakukan dengan menggunakan scatterplot. Dapat diamati bahwa titik-titik membentuk pola yang tidak jelas atau tidak berpola. Selain itu titik-titik tersebut menyebar di atas dan di bawah angka 0 pada sumbu $\mathrm{Y}$, sehingga disimpulkan bahwa tidak terjadi masalah heteroskedastisitas pada model regresi. 
Uji Regresi Linear Berganda

a. Uji Parsial

Tabel 10

Uji Parsial

\begin{tabular}{|c|c|c|c|c|c|c|c|c|}
\hline \multicolumn{9}{|c|}{ Coefficients $^{\mathbf{a}}$} \\
\hline \multirow{2}{*}{\multicolumn{2}{|c|}{ Model }} & \multicolumn{2}{|c|}{$\begin{array}{l}\text { Unstandardized } \\
\text { Coefficients }\end{array}$} & \multirow{2}{*}{$\begin{array}{c}\text { Standardi } \\
\text { zed } \\
\text { Coefficie } \\
\text { nts } \\
\text { Beta }\end{array}$} & \multirow[t]{2}{*}{$\mathrm{t}$} & \multirow[t]{2}{*}{ Sig. } & \multicolumn{2}{|c|}{$\begin{array}{l}\text { Collinearity } \\
\text { Statistics }\end{array}$} \\
\hline & & $\mathrm{B}$ & Std. Error & & & & $\begin{array}{c}\text { Tolera } \\
\text { nce }\end{array}$ & VIF \\
\hline \multirow[t]{3}{*}{1} & (Constant) & 12.492 & 1.756 & & 7.115 & .000 & & \\
\hline & $\begin{array}{l}\text { Learning from } \\
\text { home }\end{array}$ & .548 & .057 & .476 & 9.554 & .000 & .642 & 1.557 \\
\hline & Ketersediaan IT & .402 & .088 & .228 & 4.583 & .000 & .642 & 1.557 \\
\hline
\end{tabular}

a. Dependent Variable: Pemahaman Akuntansi

Berdasarkan data yang terdapat pada tabel 10, hasil analisis regresi parsial bisa diamati bahwa nilai probabilitas dari masing-masig variabel berada dibawah nilai signifikansi 0.05 maka dapat dikatakan bahwa secara parsial baik variabel Learning from home (X1) dan Ketersediaan IT berpengaruh secara signifikan dan arahnya positif terhadap variabel pemahaman akuntansi.

b. Uji Simultan

Tabel 11

Uji Simultan

\begin{tabular}{|c|c|c|c|c|c|c|}
\hline \multicolumn{7}{|c|}{ ANOVA $^{a}$} \\
\hline \multicolumn{2}{|c|}{ Model } & Sum of & $\mathrm{df}$ & Mean & $\mathrm{F}$ & Sig. \\
\hline \multirow[t]{3}{*}{1} & $\begin{array}{l}\text { Regressio } \\
\mathrm{n}\end{array}$ & 6006.914 & 2 & 3003.457 & $\begin{array}{r}128.13 \\
6\end{array}$ & $.000^{\mathrm{b}}$ \\
\hline & Residual & 8696.091 & 371 & 23.440 & & \\
\hline & Total & 14703.005 & 373 & & & \\
\hline
\end{tabular}

a. Dependent Variable: Pemahaman Akuntansi

b. Predictors: (Constant), Ketersediaan IT, Learning from home

Berdasarkan data yang terdapat pada tabel 11, hasil analisis ANOVA menunjukkan bahwa variabel Learning from Home dan Ketersediaan IT secara bersama-sama (simultan) berpengaruh terhadap Pemahaman Akuntansi. Hasil ini ditunjukkan oleh nilai probabilitas yang kurang dari $0,050(\mathbf{0 . 0 0 0}<\mathbf{0 . 0 0 0})$ dan nilai F-hitung lebih besar daripada F-tabel $(\mathbf{1 3 , 3 4 1}>\mathbf{3 , 0 2 0})$. 
c. Uji Ketepatan Perkiraan Model

Tabel 12

Uji Ketepatan Perkiraan Model

\begin{tabular}{|c|c|c|c|c|c|}
\hline \multicolumn{6}{|c|}{ Model Summary } \\
\hline $\begin{array}{l}\text { Mod } \\
\text { el }\end{array}$ & $\mathrm{R}$ & $\begin{array}{c}\mathrm{R} \\
\text { Square }\end{array}$ & $\begin{array}{l}\text { Adjusted R } \\
\text { Square }\end{array}$ & $\begin{array}{l}\text { Std. Error } \\
\text { of the } \\
\text { Estimate }\end{array}$ & $\begin{array}{l}\text { Durbin- } \\
\text { Watson }\end{array}$ \\
\hline 1 & $.639^{\mathrm{a}}$ & .409 & .405 & 4.84145 & 1.950 \\
\hline
\end{tabular}

a. Predictors: (Constant), Ketersediaan IT, Learning from home

b. Dependent Variable: Pemahaman Akuntansi

Berdasarkan data yang terdapat pada tabel 12 di atas menunjukkan nilai $\mathrm{R}$ Square sebesar 0.409, hal ini menunjukkan bahwa besarnya pengaruh Learning from Home dan Ketersediaan IT terhadap Pemahaman Akuntansi sebesar 40,9\%. Sedangkan sisanya $(59,1 \%)$ dipengaruhi oleh variabel lain yang tidak dimasukkan di dalam model penelitian.

Pembahasan

a. Learning From Home berpengaruh secara signifikan positif terhadap pemahaman akuntansi mahasiswa ( H1)

Berdasarkan uji statistik secara parsial, dihasilkan nilai probabilitas adalah sebesar 0.000 lebih kecil dari 0.05 maka hipotesis ini bisa dikatakan diterima.Penerimaan hipotesis ini sesuai dengan kerangka berfikir yang diajukan bahwa sikap mahasiswa saat pembelajaran e-larning mempengaruhi tingkat pemahaman akuntansi mahasiswa. Sikap terbuka dari mahasiswa untuk dapat menciptkan lingkungan yang nyaman saat pembelajaran e-learning dapat meningkatkan mood belajar. Kesiapan mahasiswa untuk dapat belajar secara mandiri selain juga mendapatkan pengajaran secara daring juga mempengaruhi pemahaman mahasiswa. Beberapa materi akuntansi seperti akuntansi keuangan, biaya dan investasi saat ini sudah banyak tersebar di media online.

Ketika mahasiswa merasa bahwa materi yang disampaikan secara daring belum mampu memberikan pemahaman yang memadai maka mahasiswa dapat mencari referensi secara online atau bisa juga mencari video tutorial pada materi-materi yang bersifat aplikatif seperti pembuatan laporan keuangan dan teknik penilaian invtasi atau pada keputusan-keputusan manajerial yang sifatnya taktis. Pada saat covid19 ini mahasiswa lebih banyak berada di rumah sesuai anjuran dari pemerintah, oleh karenanya mahasiswa dianggap lebih banyak memiliki waktu untuk dapat fokus bejar dibandingkan pada saat mereka belajar secara langsung di kampus. Hal ini memberikan mahasiswa lebih banyak fleksibilitas untuk mengelola waktu belajar dengan baik sehingga pembelajaran e-learning menjadi terasa menyenangkan dan tidak meimbulkan stress karena pengelolaan waktu belajar yang kurang baik. Hasil penelitian ini juga sesuai dengan penelitian Liaw, Huang, dan Chen (2007); Gel et al (2014); Masrom, M. (2007); Henry, P. (2001) yang menyatakan bahwa sikap mahasiswa dalam menghadapi pembelajaran e-larning juga merupakan faktor yang dapat mempengaruhi keberhasilan e-learning yang dapat kita lihat dari pemahamn mahasiswa pada materi yang disampaikan secara e-learning. 
b. Ketersediaan IT berpengaruh secara signiifikan positif terhadap pemahaman akuntansi mahasiswa $(\mathrm{H} 2)$

Hasil uji statistik menunjukan bahwa nilai probabilitas dari variabel ketersediaan IT terhadap pemahaman akuntansi adalah kurang dari 0.05 artinya hipotesis yang diajukan dalam penelitian ini diterima. Ketersediaan IT meliputi tersedianya sarana IT yang menunjang pembelajaran baik yang berasal dari mahasiswa, organisasi, maupun dosen diharapkan dapat membantu mahasiswa meahami materi pembelajaran secara e-learning dengan lebih baik. Pada awal implementasi e-learning ketersediaan IT ini menjadi kendala utama terutama pada platform standar e-learning namun saat ini sudah banyak perguruan tinggi yang memperbaiki sistem $e$-learningnya sehingga memudahkan dosen dan mahasiswa untuk dapat melaksanakan e-learning dengan lebih baik.

Beberapa teknologi informasi yang digunakan saat ini di Indonesia diantaranya adalah Google Classrom, youtube, google meet, zoom, teleconference call, big blue botton, Microsoft teams, dan sebagainya. Ada juga univrsitas di jawa timur yang telah mengembangkan platform e-learningnya sendiri sehingga memudahkan mahasiswa dan dosen untuk dapat melaksanakan e-learning dengan lebih baik. Ketersediaan IT ini merupakan komponen utama pada saat melaksankan e-learning. Jika teknologi informasi tidak tersedia dengan baik maka output e-learning berupa pemahaman mahasiswa atas materi yang disampaikan tidak akan tercapai. Hasil penelitian ini sesuai dengan hasil penelitian yang dilakukan oleh Delone dan McLean (1992); Pavel et al (2015); Halawi et al (2009) tentang bagaimana ketersediaan IT dapat menunjang keberhasilan pembelajaran e-learning yang dalam penelitian ini diukur dengan menggunakan pemahaman akuntansi mahasiswa baik dari segi teori maupun segi aplikatif.

c. Learning From Home dan Ketersediaan IT secara bersama berpengaruh secara positif signifikan terhadap pemahaman mahasiswa (H3)

Pada pengujian secara simultan pada model regresi dalam penelitian ini dihasilkan nilai probabilitas sebesar 0.00 dimana nilai tersebut lebih kecil dari 0.05 artinya variabel independen dalam penelitian ini yaitu learning from home dan ketersediaan IT secara bersamaan mempengaruhi pemahaman mahasiswa. Semakin baik pengaturan learning from home dan ketersediaan IT yang memadai maka akan semakin baik pemahaman mahasiswa terhadap pemahaman akuntansi. Walaupun demikian, perlu dipehatikan bahwa berdasarkan uji ketepatan perkiraan model menunjukan bahwa kedua variabel tersebut hanya mempengaruhi variabel pemahaman akuntansi sebesar $40.9 \%$. Ada variabel-variabel lain yang masih bisa menjelaskan megenai bagaimana pemahaman akuntansi terbentuk. Hal ini bisa berupa faktor eksternal seperti keisiapan pemerintah dalam mendukung sistem pembelajaran $e$ learning diantaranya adalah penyusunan kurikulum yang sesuai dengan sistem $e$ learning.

Selama ini, kurikulum yang digunakan masih kurikulum konvesional berbasis tatap muka langsung. Bagaimana konstruk pembelajaran termasuk diantaranya adalah sistem penugasan dan kepadatan materi pada masing-masing jenjang pendidikan dan tujuan pembelajaran yang ingin dicapai juga perlu disesuaikan. Selain kurikulum, hal lainnya berkaitan dengan bagaimana pemerintah dapat menjadikan e-learning dapat dilaksanakan oleh setiap pelajar dengan tidak hanya memberikan bantuan berupa keringanan pada pulsa tetapi juga pada sarana belajar seperti ketersediaan perangkat keras penunjang e-learning. Beberapa hal tersebut dapat diteliti pada penelitian selanjutnya untuk dapat mempeluas jangkauan faktor-faktor penentu keberhasilan $e$ learning. Di sisi lain, faktor spesifik yang mungkin dapat mempengaruhi pemahaman 
akuntansi mahasiswa adalah tentang kemudahan mahasiswa untuk dapat mengakses kembali video materi secara offline dan online diluar jam perkulihan terutama untuk beberapa mata kuliah yang bersifat teoritis. Sedangkan untuk materi yang bersifat aplikatif perlu untuk merancang sistem pembelajaran yang bisa mengakomodasi hal tersebut saat dilaksanakan e-learning.

\section{Kesimpulan}

Berdasarkan hasil penelitian dan analisis yang dilakukan, dapat ditarik kesimpulan sebagai berikut:

1. Variabel Learning from home berpengaruh secara positif signifikan terhadap pemahaman akuntansi mahasiswa

2. Variabel Ketersediaan IT Learning From Home dan Ketersediaan IT secara bersama berpengaruh secara positif signifikan terhadap pemahaman akuntansi mahasiswa (H3)

3. Vaariabel Learning from home dan ketersediaan IT secara bersama-sama mempengaruhi secara positif variabel pemahaman akuntantasi mahasiswa

\section{Saran}

Beberapa saran yang bisa diberikan peneliti untuk pengembangan penelitian ini di masa yang akan datang adalah:

1. Memperluas cakupan fakor-faktor yang membentuk pemahaman akuntansi mahasiswa. Misalnya saja adalah kesesuaian kurikulum dengan sistem pembelajaran e-learning

2. Memperluas cakupan data menjadi tidak hanya pada cakupan regional jawa timur tetapi menjadi cakupan nasional

3. Memperluas cakupan data yang tidak hanya melibatkan mahasiswa pada level strata 1 tetapi juga pada level vokasi.

\section{Daftar Pustaka}

Amasha, M. A., \& AbdElrazek, E. E. (2016). An M-Learning framework in the podcast form (MPF) using context-aware technology. International Journal Of Advanced Computer Science And Applications, 226-234.

Arikunto, S. (2010). Prosedur Penelitian Suatu Pendekatan Praktik. 2010. Jakarta: Rineka Cipta.

Astuti, P. U. J. I., \& Hartono, Y. U. S. U. F. (2016, September). Developing ICT-based teaching materials of English for Mathematics course. In Sriwijaya University Learning and Education International Conference (Vol. 2, No. 1, pp. 863-878).

Astuti, P., \& Febrian, F. (2019). Blended Learning Syarah: Bagaimana Penerapan dan Persepsi Mahasiswa. Jurnal Gantang, 4(2), 111-119.

Cidral, W. A., Oliveira, T., Di Felice, M., \& Aparicio, M. (2018). E-learning success determinants: Brazilian empirical study. Computers \& Education, 122, 273-290.

Cheng, Y. M. (2011). Antecedents and consequences of e-learning acceptance. Information Systems Journal, 21(3), 269-299. https://doi.org/10.1111/j.1365-2575.2010.00356.x

DeLone, W. H., \& McLean, E. R. (1992). Information systems success: The quest for the dependent variable. Information systems research, 3(1), 60-95.

Gel, Y. R., O’Hara Hines, R. J., Chen, H., Noguchi, K., \& Schoner, V. (2014). Developing and assessing e-learning techniques for teaching forecasting. Journal of Education for Business, 89(5), 215-221. https://doi.org/10.1080/08832323.2013.856281

Halawi, L. A., McCarthy, R. V., \& Pires, S. (2009). An evaluation of e-learning on the basis of Bloom's taxonomy: An exploratory study. Journal of Education for Business, 84(6), 374-380. https://doi.org/10.3200/JOEB.84.6.374-380 
Hanum, N. S. (2013). Keefetifan e-learning sebagai media pembelajaran (studi evaluasi model pembelajaran e-learning SMK Telkom Sandhy Putra Purwokerto). Jurnal Pendidikan Vokasi, 3(1).

Hartanto, W. (2016). Penggunaan E-Learning Sebagai Media Pembelajaran. Jurnal Pendidikan Ekonomi: Jurnal Ilmiah Ilmu Pendidikan, Ilmu Ekonomi dan Ilmu Sosial, 10(1).

Henry, P. (2001). E-learning technology, content and services. Education+ Training. https://news.detik.com/berita/d-4991485/kapan-sebenarnya-corona-pertama-kali-masuk-ri

Liaw, S. S., Huang, H. M., \& Chen, G. D. (2007). Surveying instructor and learner attitudes toward e-learning. Computers \& Education, 49(4), 1066-1080. https://doi.org/10.1016/j.compedu.2006.01.001

Masrom, M. (2007). Technology acceptance model and e-learning. Technology, 21(24), 81.

Pavel, A. P., Fruth, A., \& Neacsu, M. N. (2015). ICT and e-learning-catalysts for innovation and quality in higher education. Procedia economics and finance, 23, 704-711. https://doi.org/10.1016/s2212-5671(15)00409-8

Pemerintah Indonesia (2020), Peraturan Pemerintah Nomor 21 Tahun 2020 tentang Pembatasan Sosial Berskala Besar dalam rangka Percepatan Penanganan Corona Virus Disease 2019 (COVID-19) (PDF), Jakarta: Kementerian Sekretariat Negara Republik Indonesia.

Romi, I. M. (2017). A model for e-Learning systems success: systems, determinants, and performance.

Samarasinghe, S. M., \& Tretiakov, A. (2009). A multi-dimensional measure of e-learning systems success. Proceedings ascilite Auckland, 908-910.

Stricker, D., Weibel, D., \& Wissmath, B. (2011). Efficient learning using a virtual learning environment in a university class. Computers \& Education, 56(2), 495-504. https://doi.org/10.1016/j.compedu.2010.09.012

Sugiyono, M. P. P., \& Kuantitatif, P. (2009). Kualitatif, dan R\&D, Bandung: Alfabeta. Cet. VII.

Yusup, F. (2018). Uji validitas dan reliabilitas instrumen penelitian kuantitatif. Tarbiyah: Jurnal Ilmiah Kependidikan, 7(1). 